provided by the Imperial College. Although the scientific staff under Wimperis was never more than half a dozen, the laboratory was no politician's plaything but one which for several years after the War continued to be an outstandingly virile centre of research on such diverse fields as aircraft engines, navigation aids and the effects of bombing on ships' structures.

When in 1925 the Air Ministry decided to follow the example of the Admiralty and create the post of director of scientific research, it was no surprise to those who had worked with Wimperis that he was asked to fill it; this he did until 1937. Much might be written of Wimperis in those years, for he was eager to pursue new and seemingly umpromising ideas while possessing a flair for detecting the bogus. $\mathrm{He}$ encouraged the Cierva autogyro, and in 1934 caused the formation of the Committee for the Scientific Survey of Air Defence, under the chairmanship of Sir Henry Tizard, the work of which was a major factor in transforming the whole picture of air defence. Wimperis also caused a revitalization of the Royal Aircraft Establishment of his day, and, most important of all, sowed much in defence science administration that others, with more imposing titles and more generous recognition, were to reap in the decades to come.

How much a man accomplishes for all to see must be judged in relation to whether wind and tide are for or against him. As the first director of scientific research at the Air Ministry, Wimperis had an unenviable task. Not all Civil servants were happy that a scientist should hold a responsible post; the fears of senior Royal Air Force officers led to the ridiculous edict that Wimperis was to have nothing to do with armament, that is, with the chief purposes of Service aircraft. Others caused a ban on concern with lighter-than-air craft, a restriction which did not prevent Wimperis from protesting against the premature and disastrous flight of the $R 101$. On a lighter note, it is amusing to recall that when Wimperis asked that a copy of Nature should be regularly provided for him, discreet inquiries revealed that it was not a salacious journal! By the exercise of patience, wisdom and courage, Wimperis gradually enhanced the respect for science in the Air Ministry and when he retired in 1937 the dictum was dying that "a scientist should be on tap but not on top".

On retirement, Wimperis accepted an invitation to Australia to advise the Commonwealth Government on aeronautical research. It was during this visit that the University of Melbourne conferred on him the honorary degree of doctor of engineering. Largely as a result of Wimperis' recommendations, a Division of Aeronautics was set up under the Australian Committeo for Scientific and Industrial Research and a chair of aeronautics established at the University of Sydney, though Wimperis could not have foreseen that aeronautical research and development in Australia would be hindered by a reluctance in that country to manufacture aircraft.

During a stay in Singapore, Wimperis developed tropical sprue, which for twenty years was to call for fortitude on its victim's part and for devotion to his special needs by his wife, who survived him by only three weeks. In spite of a gradually increasing physical frailty, his range of interests widened further, and for several years he was convenor for the atomic energy study group at Chatham House.

One who knew him well, wrote these words of him : "Wimperis at the Air Ministry could be stern and biting, never suffering fools or the lazy or the selfdeluded gladly but he was tender and helpful to the eager, the struggling and to those who showed courage in difficulties. He cared intensely for truth, honesty and intellectual and personal integrity and had a deep regard for some who stood for complementary values".

Add to these attributes a strong sense of humour and we have a fair picture of Dr. Wimperis, who survived many of his friends and is mourned by many more.

A. P. ROWE

\section{Mr. W. J. Chalk}

Mr. W. J. Chalk, a member of the engineering staff of the British Broadcasting Corporation, died suddenly on September 24 at the age of sixty-one. His early interest in the field of communications led to his active service during the Second World War in the Royal Signals. He retired with the rank of lieutenant-colonel after having held a number of staff appointments as Radio Planning Officer in Europe and in the Middle- and Far-East. After the War he became a member of the Allied Control Commission in Germany; and, as the liaison engineer with the North-west German Broadzasting Organization, he represented the United Kingdom High Commission at the European Broadcasting Conference at Copenhagen in 1950.

Mr. Chalk joined the British Broadcasting Corporation in 1951, and, as a member of the Engineering Information Department, he became responsible for matters concerning frequency allocations and radio interference problems in the broadcasting field. His earlier experience in world-wide communications made him a valuable member of the United Kingdom delogation at intermational conferences. During recent years he had participated in the plenary assemblies of the International Radio Consultative Committee held at Geneva (1953), Warsaw (1956) and Los Angeles (1959). In 1959, also, he was a member of the British Broadcasting Corporation's delegation to the Administrative Radio Conference in Geneva, which established revised regulations and frequency allocations for the conduct of international radio communications of all types. His work in this field made him widely known both in Britain and overseas. He was very popular with both his British and his foreign colleagues, and had a reputation for exercising a sound judgment on all the problems with which he was concerned. R. L. Smrth-Rose

\section{Prof. E. W. Goodpasture}

The death of Prof. Ernest W. Goodpasture at the age of seventy-nine is reported from the United States. He was a pioneer in the field of the pathology of virus infections.

Goodpasture was born in Tennessee, and thero received his medical training at Vanderbilt University, Nashville, where he was for so long to hold the chair of pathology. He went to Yalo and to Baltimore for postgraduate training ; at Johns Hopkins he held a Rockefeller fellowship in pathology. In 1929 he was called to the chair of pathology at Nashville and here he remained until 1955.

His early work in the virus field was on herpes simplex, particularly on the progression of the virus along nerves. Turning to the pox group, he studied the inclusion bodies of fowl-pox, and in 1931, with 
A. M. Woodruff, cultivated the virus on the chorioallantoic membranes of fertile eggs. Rous and Murphy had twenty years earlier used a similar technique in studies of tumours, including the Rous sarcoma; but Goodpasture and his colleagues really introduced the developing egg into virus research. Later, Burnet improved the method by showing how to make an artificial air-sac. In 1938 Goodpasture showed that viruses would grow after inoculation into the amniotic cavity of chick embryos ; and this method, too, was taken up and developed by Burnet, and other workers. For many years Goodpasture worked with fertile cggs and used them for many purposes and to great advantage. He grew vaccinia on chorioallantoic membranes and advocated the use of such material for vaccination against smallpox. He grew 'difficult' viruses such as herpes zoster on grafts of human skin growing in eggs. He studied the behaviour in cells of egg membranes of some specialized parasites among the bacteria such as those of typhoid and tularæmia. The laboratory study of mumps really begins with his demonstration that monkeys can be infected by inoculation into their parotids.

Goodpasture held many important appointments, including that of scientific director of the International Health Division of the Rockefeller Foundation. On his retirement from Vanderbilt in 1955 he went to work at the Armed Forces Institute of Pathology in Washington. He was a member of the National Academy of Sciences and of the Amorican Philosophical Society and received many honours.

C. H. ANDREWES

\section{NEWS and VIEWS}

\section{Nobel Prize for Chemistry}

Prof. Willard F. LibBy has been awarded the Nobel Prize for Chemistry for 1960 in recognition of his work on the carbon-14 method of age determination. In a series of experiments carried out during the period following his appointment as professor of chemistry at the Institute of Nuclear Studies, University of Chicago, Prof. Libby demonstrated the presenco of carbon-14 in Nature at a level close to that which he had predicted, and showed that its distribution throughout the world-wide carbon exchange reservoir is substantially uniform. He then pointed out that the death of an organism would prevent further exchange of its carbon atoms with those of the reservoir and that consequently a measurement of the residual carbon-14 activity of dead material could be used as a basis for an age detcrmination. The practical application of the method necessitated the development of an experimental technique capable of moasuring accurately, and on a routine basis, the extremely low levels of carbon-14 activity which are found in ancient materials. Libby's succoss in this direction can best be judged by the list of nearly a thousand dates produced by tho Chicago dating laboratory during its period of operation. The importance of the mothod is incalculable, for it provides not only an absolute method of dating independent of hypothetical considerations covering the past 40,000 years or so, but also one which is of world-wide application to a variety of commonly occurring materials. Archæology, geology, oceanography and climatology have all benefited and will continue to do so in the future from the applications of Libby's fundamental researches.

\section{Nobel Prize for Physics}

THE announcement of the award of the Nobel Prize for Physics for 1960 to Prof. Donald A. Glaser of the Radiation Laboratory, California, has given pleasuro to all who admire the way in which a young man not only conceived a brilliant idea but also, using commonplace physical ideas as a basis for his oxperimental work in an unexplored fiold, and working practically alone, presented the nucloar physicist with a poworful new tool-the liquid bubblo chamber. The formation of bubbles along the track of an ionizing particle occurs in a medium of much groater stopping power than the gas in a cloud chamber, yot because of the short time (only a fow milliseconds during which the liquid is rendered sensitive to such bubblo formation it is possible to follow the various products of a particular nuclear reaction without the ambiguity, inherent in nuclear emulsions, caused by the presence of many other, oxtraneous, tracks. Chambers containing hundreds of litres of liquid, set up beside existing high-energy particle accelera. tors, can now produce photographs of nuclear events every fow seconds and in this way not only has the existence of the neutral cascado particle been established but also now experimental data are being made available at such a greatly increased rato that only by the use of automatic measuring devices can the fullest advantage be taken of Prof. Glaser's great contribution to physics.

\section{Royal Society: Award of Royal Medals}

H.M. THe QueEn has been graciously pleased to approve recommendations made by the Council of the Royal Society for the award of the two Royal Medals for the current year as follows: to Sir Roy Cameron, professor of morbid anatomy at University College Hospital Medical School in the University of London, for his distinguished contributions in the field of cellular pathology; to Prof. A. C. B. Lovell, professor of radio astronomy in the University of Manchester and director of the Nuffield radio astronomy laboratories, Jodrell Bank, for his distinguished contributions to radio astronomy.

\section{Applied Mechanics at Nottingham :}

Prof. G. B. Warburton

DR. G. B. Warburton, who has been appointed to the recently instituted chair of applied mechanics in the University of Nottingham, studied at Peterhouse, Cambridge, and was awarded first-class honours in the Mechanical Sciences Tripos in 1944. As a demonstrator at Cambridge, he was attached to a research team investigating stresses set up in ships' platos due to welding. Later he became an assistant lecturer at University College of Swansea and, in 1947, joined the engineoring staff at the University of Edinburgh. Aftor varied teaching experience, Dr. Warburton was appointed head of the Postgraduate School of Applied. Dynamies which was formed at Edinburgh in 1956, details of which appeared in Nature, 179, 1177 (1957). His research work at Edinburgh has 